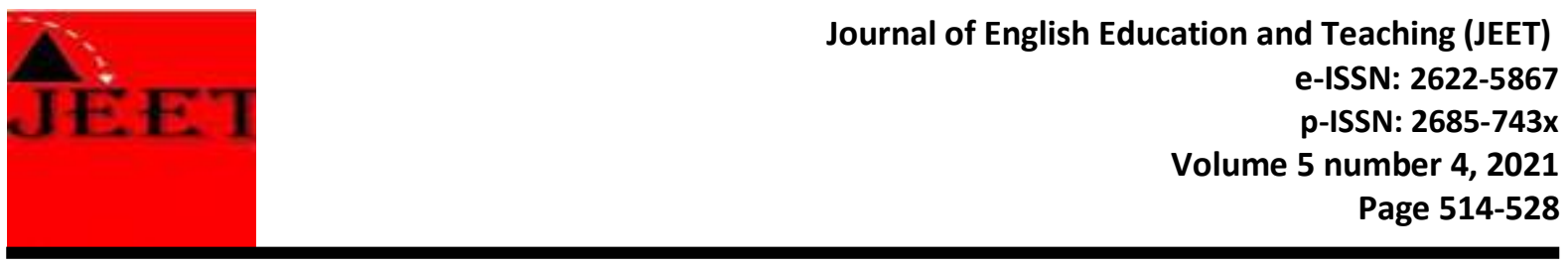

\title{
An Analysis of English Diphthong Pronunciation by the Students of the English Education Study Program
}

\author{
Sefran Ponidi \\ University of Bengkulu \\ sefranponidi@gmail.com \\ Syafrizal Sabarudin \\ University of Bengkulu \\ syafrizal@unib.ac.id \\ Arasuli \\ University of Bengkulu \\ arasulimsi@gmail.com
}

Corresponding email: sefranponidi@gmail.com

\begin{abstract}
This research was aimed to know how English students in University of Bengkulu, English Education Study Program pronounced English Diphthongs. This research used descriptive qualitative method. The population in this research was the 79 sixth semester students of English Education Study Program. The numbers of samples were $20 \%$ of the population. The Students were asked to pronounce 8 diphthongs in English. The research was doing input the audio from native speaker and data recorded by each student into Audacity. Then, comparing both of the data. The research was using Audacity as the technology to analyze and to see the pattern of the data recorded in order to check the correct and incorrect of the students' pronunciation. The data of the research consisted of 8 diphthongs and each diphthong consisted of 3 words including in the word diphthongs. The total words in this study were 24 words. The result of this research showed that most of English students pronounced English diphthongs [er], [ov],

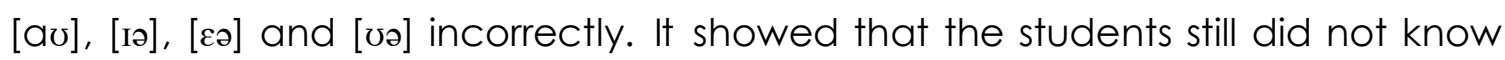
about English diphthongs. Meanwhile, the students were good at pronouncing diphthongs such as [aI] and [эI] with more than $58 \%$ of correct pronunciation.
\end{abstract}

Keywords: English diphthong, Pronunciation, English Students

\section{Introduction}

Students need to communicate with the purposes of conveying feelings and thoughts, desires, meeting their needs, and exchanging information in every aspect of their lives. The main purpose of foreign language education just 
as in native language education is to improve an individual's comprehension and speaking skills in the target language in order to be able to communicate (Cetin, 2017, p. 362).

Speaking is an important language skill in terms of all learning fields and expressing self (Akyol, 2014, p. 23). Speaking requires skills such as choosing the right words, structuring meaningful syntax, creating prosodic structure, and articulating according to phonetic characteristics (Cetin, 2017, p. 364).

Communication relates to pronunciation. Pronunciation is one of language components which is really important to be mastered by students. Mastering language components will influence students to master all language skills. Pronunciation is important to proper communication because the incorrect use of pronunciation leads to the message being misunderstood by the listener. Mastering the sounds and pronunciation of the target language is a high priority for the speaker of English (Chongning, 2009:39). In mastering language, to have a good pronunciation of the language can help in normal communication, particularly intelligibility. In other words, a good pronunciation can make the communication with other people nature and easy to understand about the meaning of the content in conversation or daily life.

In pronunciation we have to be aware about the indicators of pronunciation. According to Djiwandono (2008:124-125), there are four indicators of pronunciation, there are 4. First, intelligibility is pronounced of the whole text and its parts are heard clearly or not causing misunderstanding. Second, Fluency is as a whole of text can be pronounced fluently. Third, Accuracy is words and parts of text are pronounced accurately. Fourth, Nativelike is pronounced of the whole text and its parts are pronounced like native speaker.

Pronunciation can be defined as the way a certain sound or sounds are produced; stress (i.e the pronunciation of a word (in a sentence) or syllable (in a word) with more than the surrounding words syllables); intonation (i.e the rise and fall of the pitch of the voice in speaking, especially as this affects the meaning of what is said) (Fachrurrazy, 2002:57)

In English, there is no one-to-one relation between the system of writing and the system of pronunciation. According to Diana (2017), The alphabet 
which people use to write English has 26 letters but in (Standard British) English there are approximately 44 speech sounds. The number of speech sounds in English varies from dialect to dialect, and any actual tally depends greatly on the interpretation of the researcher doing the counting.

The worst thing is if they have wrong pronunciation, it can lead two things between speaker and listener which are negative impression and miscommunication. First for negative impression, if the speaker talks in a conversation to other, the listener can understand about the limitation of grammar and vocabulary. Therefore, they will notice right away if the speaker's pronunciation is good or bad. The bad pronunciation can lead the bad impresssion of speaker. Second for miscommunication, if the speaker's pronunciation is bad, it will be not heard clearly and easily to be understood. For example, word end which means finish, will be interpreted as and which means similarity. This will be a bad conversation at the end. Based on the explanation above it can be concluded, good pronunciation should be one of the most important things in English in order to avoid negative impression and miscommunication.

In Indonesia, learning English with correct pronunciation is difficult. They have some problems in pronunciation which are affected by some factors such as; the differences of accents, behavior, culture, mother tongue and the language itself. The reasons why learning another language pronunciation are difficult; first, some sounds of the new or target language does not exist in learner' native language. The second, the difference of distribution between native language and the target language.

In specifically, the Indonesian students commonly have problems in pronouncing English words correctly because their native language does not have same system of speech sounds. For example, English has eight diphthong such as [eı], [ov], [aı], [av], [эг], [ı], [عə] and [və]. English diphthong is divided into two types. Those are English closing diphthong and English centering diphthong. The English closing diphthong is diphthongs that the second vowel is closest than the first vowel. The English centering diphthong is diphthongs that the second vowel is more center than the first vowel (Ramelan 1999:84-98). But, in Indonesia there are three kinds of known diphthong such as [ar], [av] and [эI]. 
Some researchers have conducted researches related to speaking ability. The first research was from Sumbayak (2009) who was student of English Education Study Program of University of Riau. The title is "The Diphthong: The Obstacles for Indonesian Speaker of English ". In this research the researcher only took two diphthong English about [er] and [ov].

The second research from Saebani (2016) who was student of English Education Study Program of Institute for Islamic Studies (IAIN) Salatiga. The research was about "An Analysis of Student's Pronunciation of Centering Diphthong Equipped by Phonetic Transcriptions". This research was analyzing the pronunciation of centering diphthong to fourth semester students. And the result showed that almost the students did not understand about the phonetic transcription and centering diphthong.

The third research from Deiniatur (2015) who was student of English Education Study Program of Institute for Islamic Studies (IAIN) Jurai Siwo Metro. The title of the research is "An Analysis of Student's Errors in Pronuncing Diphthongs at the first semester of STAIN Jurai Siwo Metro". The result showed that the students made errors out of the total 499 words.

The fourth research was by Nadia Agustin (2019) with the Title "The Analysis of Factors that Affect Students Anxiety in Speaking for Presentation Class (A Study of the Fourth Semester Students at the English Education Study Program of University of Bengkulu in Academic Year 2018/2019). The result of the research were 1 student (1.75\%) was indicated in "Very Anxious" level, 3 students (5.26\%) were indicated in "Anxious" level, 50 students (87.71\%) were indicated in "Mildly Anxious" level. 3 students (5.26\%) were indicated in "Relaxed" level, and 0 students (0.00\%) were indicated in "Very Relaxed" level. The data indicate that the majority of the students (50 out of 57 ) were in the level of Mildly Anxious.

The last by Syafriadin (2019) with the Title "Digital Stortelling Implementation for Enhancing Students' Speaking Ability in Various Text Genres". The research was investigating the impact of digital storytelling towards senior high school students' speaking ability in various text genres. The researcher found that in Cycle 1, only 15 students $(44,1 \%)$ could pass standard minimum criteria (KKM) with the upper value 75. On the other hand, Cycle 2 
showed 27 students could achieve KKM. The researcher found some evidence on it. Digital storytelling gave some of advantages in education and technology field.

From the previous studies above, two out of five previous studies foucused on the speaking ability. Furthermore, three out of five previuos studies focused on ability of students in pronouncing English diphthong but not all of diphthongs were studied by the researchers. Meanwhile,

\section{Research Methodology}

The research used qualitative method as a research design. This research was descriptive study as a research design. According to Aggarawal (2008) descriptive research is related with gathering the information about prevailing conditions or situations for the purpose of description and interpretation. Burns and Grove (2003:295) defines a research design as "a blueprint for conducting a study with maximum control over factors that may interfere with the validity of the findings".

The population of the research took English Education Department Students at the University of Bengkulu at 6th semester who already Phonetics and Phonology course. The total population was 79 students. Sample of this research was 20 students of English Education at the University of Bengkulu. The instrument in this research was recording. After that the research compared between students and native speaker. To made sure the result was valid or not, the researcher used Audacity as the technology to see the pattern of the data recorded in order to check the correct and incorrect of the students' pronunciation. The words that used in this research have been validated by Mr, Imranudin as a lecturer in English Education Study Program of University of Bengkulu.

After getting the data, the researcher used some steps in analyzing the data as the follow: first, downloading the audio from Oxford Learner's Advanced Dictionary online version. Second was doing input the audio from each student to Audacity and cutting the audio which pronounced words of diphthong. Third was doing input the audio from native speaker and data recorded by each student into Audacity. Fourth was comparing both of the 
data. Fifth was using Audacity as the technology to analyze and to see the pattern of the data recorded in order to check the correct and incorrect of the students' pronunciation. Sixth was describing the final results. The last was drawing conclusion and suggestion.

\section{Findings and Discussion}

\section{Findings}

The English centering diphthong is diphthongs that the second vowel is more center than the first vowel. The English closing diphthong consists of [ $\left.e_{I}\right]$, [Ov], [aI], [av], and [эI]. The English centering diphthong consists of [Iə], [عə] and [və]. Every diphthong was put into a word, so the total of words was 24 words. The total data recorded were 480 by all of participants or 20 English students in English Education Study Program, Classes A and B at sixth semester Academic Year $2017 / 2018$. The data were obtained by recording students' pronunciation first, and then comparing the students' pronunciation with the Received Pronunciation.

The result of this research showed that most of students pronounced

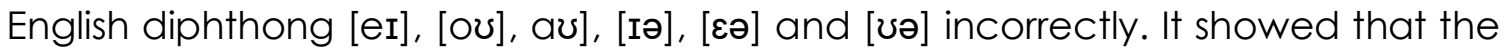

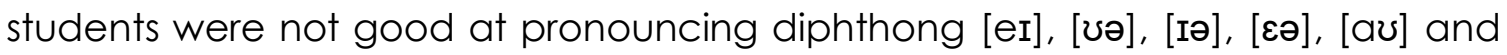
[ov]. Meanwhile, the students were good at pronouncing diphthong [aI] and [गI].

The data recorded were analyzed with put the data into Audacity to see the pattern of the data recorded in order to check and the correct and incorrect of the students' pronunciation and to compare native speaker pronunciation with English students' pronunciation. Below is one of the examples of analysis by using Audacity.

\section{Figure 10. Diphthong [eI] in the Word "Same" Pronounced by Native Speaker} and Student $4(\sqrt{ })$ 


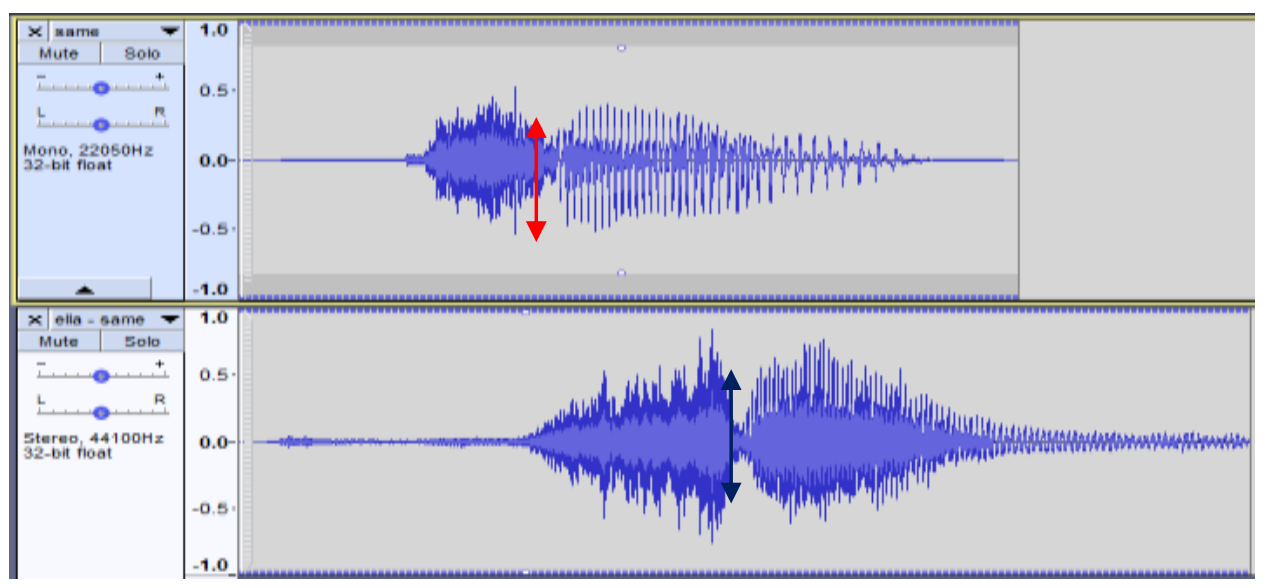

where::

Diphtong[ei] used by native speaker in pronouncing the word "Same"

Diphtong[e] used by student 4 in pronouncing the word "Same"

Figure 11. Diphthong [eI] in the Word "Same" Pronounced by Native Speaker and Student $9(\times)$

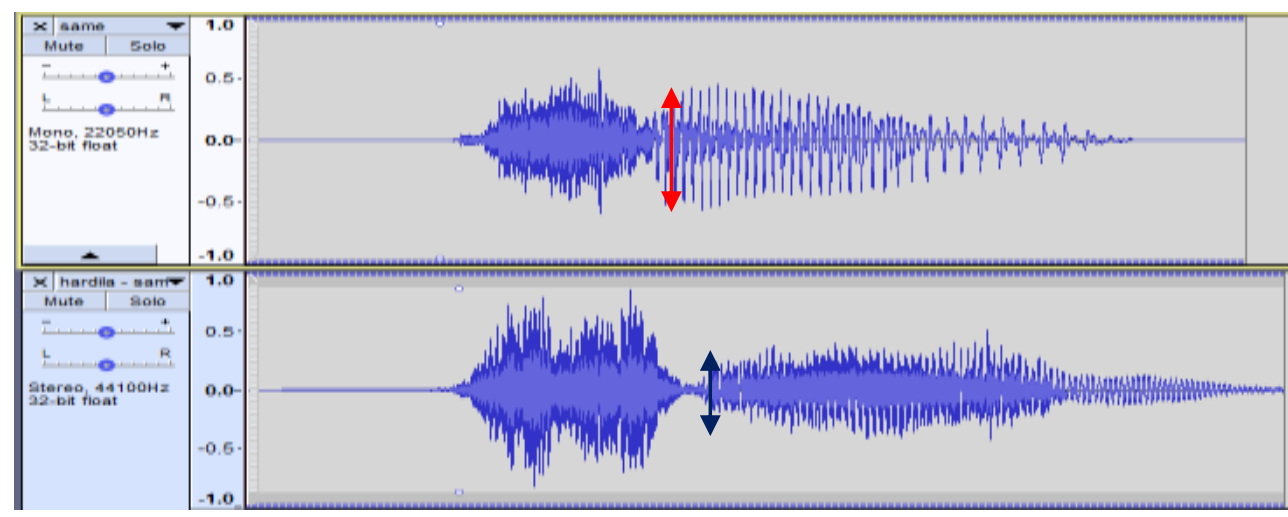

where::

Diphtong [er] used by native speaker in pronouncing the word "Same"

Diphtong [e] used by student 9 in pronouncing the word "Same" 
Figure 9 and 10 showed the comparison between native speaker and student 4 pronunciation. The amplitude of diphthong [e्] between native and student was similar and not similar. It could be seen through red and blue line which showed in figure 3 and 4 native and student pronunciation. Based on the descriptive analysis above, the researcher got the percentage of the students who pronounced English diphthong correctly and incorrectly.

Table of The Percentages of the Students' Diphthong Pronunciation Correctly and Incorrectly.

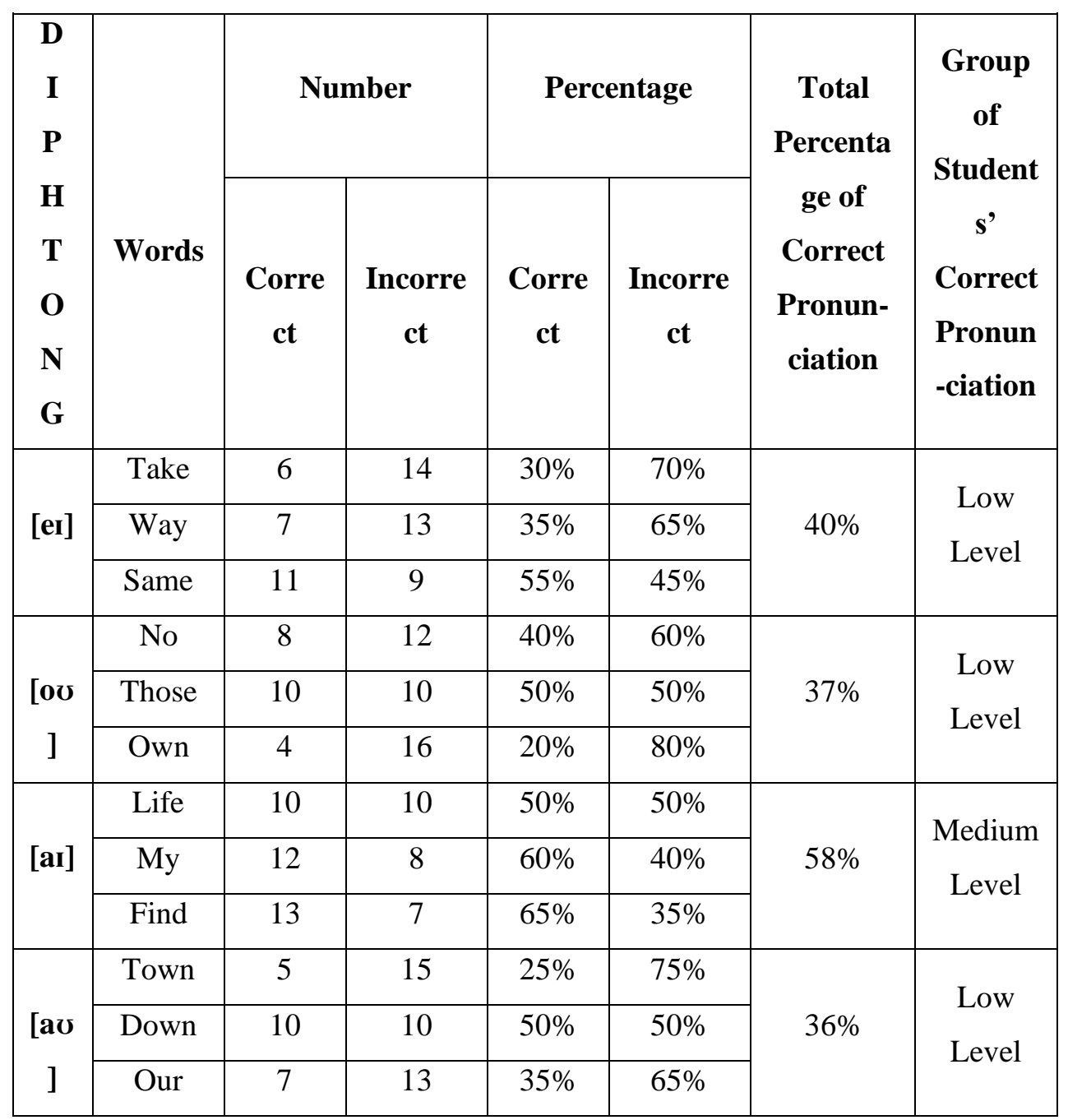




\begin{tabular}{|c|c|c|c|c|c|c|c|}
\hline \multirow{3}{*}{ [गI] } & Join & 12 & 8 & $60 \%$ & $40 \%$ & \multirow{3}{*}{$60 \%$} & \multirow{3}{*}{$\begin{array}{c}\text { Medium } \\
\text { Level }\end{array}$} \\
\hline & Oil & 10 & 10 & $50 \%$ & $50 \%$ & & \\
\hline & Choice & 14 & 6 & $70 \%$ & $30 \%$ & & \\
\hline \multirow{3}{*}{ [Іә] } & Near & 4 & 16 & $20 \%$ & $80 \%$ & \multirow{3}{*}{$18 \%$} & \multirow{3}{*}{$\begin{array}{l}\text { Low } \\
\text { Level }\end{array}$} \\
\hline & Hear & 3 & 17 & $15 \%$ & $85 \%$ & & \\
\hline & Real & 4 & 16 & $20 \%$ & $80 \%$ & & \\
\hline \multirow{3}{*}{ [عə] } & Care & 5 & 15 & $25 \%$ & $75 \%$ & \multirow{3}{*}{$21 \%$} & \multirow{3}{*}{$\begin{array}{l}\text { Low } \\
\text { Level }\end{array}$} \\
\hline & Wear & 4 & 16 & $20 \%$ & $80 \%$ & & \\
\hline & Hair & 4 & 16 & $20 \%$ & $80 \%$ & & \\
\hline \multirow{3}{*}{ [ஏə } & Pure & 2 & 18 & $10 \%$ & $90 \%$ & \multirow{3}{*}{$23 \%$} & \multirow{3}{*}{$\begin{array}{l}\text { Low } \\
\text { Level }\end{array}$} \\
\hline & Tour & 9 & 11 & $45 \%$ & $55 \%$ & & \\
\hline & Poor & 3 & 17 & $15 \%$ & $85 \%$ & & \\
\hline
\end{tabular}

The data from the table showed the number and percentage of students who pronounced English diphthong incorrectly. As can be seen from the table, there is the result from two types diphthong (Closing and Centering). Closing diphthong consists of [er], [Ov], [aI], [av], [эI] and Centering diphthong consists [эə], [عə], [ซə].

The result of closing diphthong. First, diphthong [er] consisted of words Take, Way and Same. For the words Take 70\% (14 students) pronounced incorrectly, Way 65\% (13 students) pronounced incorrectly, Same 45\% (9 students) pronounced incorrectly. Second, diphthong [ov] consisted of words No, Those and Own. For the words No 60\% (12 students) who pronounced diphthong [Ov] incorrectly, Those 50\% (10 students) who pronounced diphthong [Ov] incorrectly, Own 80\% (16 students) who pronounced diphthong [ov] incorrectly. Third, diphthong [ar] consisted of words Life, My and Find. For the words Life 50\% (10 students) pronounced incorrectly, My 40\% (8 students) pronounced incorrectly, Find 35\% (7 students) pronounced incorrectly. Fourth, diphthong $[\mathrm{av}]$ consisted of words Town, Down and Our. For the words Town 75\% (15 students) who pronounced diphthong [av] incorrectly, Down 50\% (10 students) who pronounced diphthong [av] incorrectly, Our 65\% (13 students) who pronounced diphthong [av] incorrectly. Fifth, diphthong [गI] consisted of words Join, Oil and Choice. For the words Join 40\% (8 students) who pronounced 
diphthong [ग] incorrectly, Oil 50\% (10 students) who pronounced diphthong [эг] incorrectly, Choice 30\% (16 students) pronounced it incorrectly.

The result of centering diphthong. First, diphthong [iә] consisted of words Near, Hear and Real. For the words Near 80\% (16 students) pronounced incorrectly, Hear 85\% (17 students) pronounced in wrong way, Real 80\% (16 students) pronounced incorrectly. Second, diphthong [ $\varepsilon$ ] consisted of words Care, Wear and Hair. For the words Care 75\% (15 students) pronounced incorrectly, Wear 80\% (16 students) pronounced incorrectly, Hair 80\% (16 students) pronounced incorrectly. Third, diphthong [və] consists of words Pure, Tour and Poor. For the words Pure 90\% (18 students) pronounced incorrectly, Tour 55\% (14 students) pronounced incorrectly, Poor 85\% (17 students) pronounced incorrectly.

Based on the total percentages of the students' correct diphthong pronunciation, it showed that the diphthong [ı], [عə] and [ซə] became the three lowest percentages of the students' correct pronunciation. It means that the lowest correct diphthong pronunciation, the incorrect diphthong pronunciation became higher.

As can be seen in the table 2, 18\% students pronounced diphthong [Iə] correctly or in other word, $82 \%$ from total of the students pronounce the words contained diphthong [г] incorrectly. Second, $21 \%$ students pronounced diphthong [ $\varepsilon$ ə] correctly. In other word, $79 \%$ from total of the students pronounce the words contained diphthong [eə] incorrectly. Third, 23\% students pronounced diphthong [və] correctly. In other word, $77 \%$ from total of the students pronounce the words contained diphthong [və] incorrectly.

\section{Discussion}

The result confirmed that there were difficulties for Indonesian speakers to pronounce English diphthongs correctly that are not found in Indonesian. That makes the situation where the students did not know to pronounce diphthong words correctly.

There are some factors that are of major importance when students mispronounce many of the pronunciation in this study. First, in Indonesia has only three diphthongs ex. [aI], [av] and [or] (AGPS, 1986). For many students, 


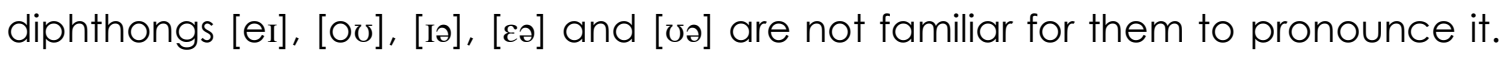
Second, the absence of learning that teaches students about pronunciation in depth. They are only know about the words but they do not know how to pronounce it correctly. Third, the differences in pronouncing words between English and Indonesian language. In pronouncing words, the speaker should know how to produce sounds acceptable (Irianto, 2018).

The result above showed the correct pronunciation of all 8 diphthong sounds were classified into 3 groups (High, Medium and Low level) but in this research, the researcher was finding only gained the data with 2 categories (Medium and Low). The correct pronunciation of two diphthongs such as [ar] and [or] was categorized at medium level. It means the students were good enough at pronouncing these diphthong. It was proven by the fact that more than $58 \%$ of the students pronounced these diphthongs correctly. The highest incorrect pronunciation by the students occurred for diphthong [I?] in word Hear/Hiar, when the students' amplitude was not similar with the native speaker. The factor of incorrect pronunciation of this diphthong is not familiar with students.

Words pronunciation in this study became a major factor. Most of all students pronounced the word in this study were not use diphthong correctly. The errors in pronouncing English diphthongs are assumed to be affected by many factors. One of the factors is the habit of students in pronouncing the word that contains of diphthongs. The habit can be from imitating, mishearing, and mispronouncing. The second is because the students pronounced the word as it was written in the orthographic writing (Deiniatur, 2015).

The correct pronunciation of five diphthongs such as [eI], [ov], [av], [cə] and [və] was categorized at low level. It means the students were not good at pronouncing these diphthongs by the fact that the correct pronunciation was less than $50 \%$. As can be seen in the result above, the highest percentage of incorrect pronunciation was [I] with only $18 \%$ of students pronounced it correctly. It meant the ability of the students at pronouncing this diphthong was low.

It means the students were not good in pronouncing these diphthongs by the fact that the percentage of correct pronunciation was about $18 \%-40 \%$. For 
vowel [ı] in three, there were only $18 \%$ of the students pronouncing this diphthong correctly. They didn't used diphthong [rə] correctly. It can be seen in the result. It showed the difference amplitude of diphthong [ı] between native speaker and students.

For diphthong [عə], there were $21 \%$ of the students pronounced it correctly. This diphthong consisted of three words such as Care, Wear and Hair. These three words were pronounced incorrectly by making the amplitude of [cə] not similar with the native speaker. For word Wear and Hair, many of the amplitudes were no indentation like native speaker. The incorrect pronunciation was caused by diphthong [عə] was not familiar to Indonesian students since this sound did not exist in Indonesian Language.

For diphthong [aI] and [эr] were categorized medium level. For diphthong [aI] were $58 \%$ correct pronunciation. This diphthong consisted of three words such as Life, My, Find. These three words were pronounced correctly because these words were familiar for the students. For example, the word My was learned by students from elementary school. That was a reason for diphthong [aI] with 58\% correct pronunciation in this study. For diphthong [or] were $60 \%$ correct pronunciation. This diphthong consisted of three words such as Join, Oil, Choice. These three words were pronounced correctly because the diphthong [э] was inside of the words and it made easier for students to pronounce it correctly.

Factors that cause errors in pronunciation for Indonesian speakers are different ways of speaking with English speakers. In Indonesia the speaker reads the word by looking and saying according to what they see without any change in voice. For example word Down, for English speakers they say the word by changing the letter /o/ to be /a/ or they are saying the word with /Daun/. Meanwhile, for Indonesian speakers the word Down they still say the letter /o/ and does not change at all or they are saying the word /Doun/. English is considered has one of the spelling systems the most difficult in the world (Dewi \& Yadi, 2017). So, that is one of reason why Indonesian speakers find it difficult to pronounce words in English properly and correctly.

By looking at the result above, this result had same result with the previous studies were Sumbayak (2009) and Deiniatur (2015) where the English Students 


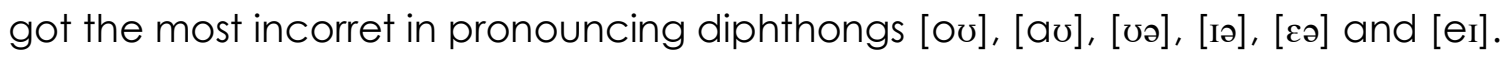
Meanwhile, another one previous study was Saebani (2016) is not similiar with this research.

\section{Conclusion}

After getting the data and analyzing the result, the researcher concluded that most of the students of this research pronounced diphthong vowels incorrectly, especially [eI], [av], [ı], [عə], [ov] and [və]. The students were not good at pronouncing these diphthongs that can be seen from the data analysis that explained these diphthong only gained $18 \%-40 \%$ or in low level category. This case happened because the students' speech organs have never been trained to pronounce these diphthongs and the diphthongs are not familiar for the students. So, there are many students did not know how to pronounce the diphthongs properly and correctly.

This research also found that the highest percentage of correct pronunciation was diphthong [ar], and [0r] by the fact that more than $58 \%$ of students pronounced this diphthong correctly. This is still not good but this proves that not all of it is wrong in its pronouncing. This case happened because the Indonesian students will have problem to pronounce this diphthong since their speech organs have never been trained to pronounce it. As the result, they replace this vowel to another vowel.

\section{References}

Aggarawal Y. P.(2008). Science of Educational Research. Nirmal Book Agency.

Agustin, Nadia. (2019). The Analysis of Factors that Affect Students Anxiety in Speaking for Presentation Class (A Study of the Fourth Semester Students at the English Education Study Program of University of Bengkulu in Academic Year 2018/2019), Journal of English Education and Teaching, 3(1), 116-127.

AGPS.(1986).Asian Language Notes-Some Likely Areas of Difficulty for Asian Learners of English, No.3. Indonesian/Malay. $2^{\text {nd }}$ edition. Canberra: Australian Government Publication Service. 
Akyol, H. (2014). Turkish teaching methods (7th Edition). Ankara: Pegem Academy Publishing.

Burns, N \& Grove, SK (2003): The practice of nursing research: Conduct, critique and utilization. Toronto: WB Saunders.

Cetin, D. (2017). Language skills - expression (speech and writing skills)] H. Develi and others (Eds.), In the Handbook on Teaching Turkish as a Applied Foreign Language (pp. 359-424). Istanbul: Kesit Publishing.

Chongning. (2009). "Student's feedback to their pronunciation learning". CELEA Journal, 38

Deiniatur. (2015). An Analysis of Students' Error in Pronouncing English Diphthongs at The First Semester of STAIN Jurai Siwa Metro. STAIN Metro.

Diana. (2017). English Students' Monophthong Vowel Pronunciation (A Case Study In University of Bengkulu, English Education Study Program, Class A, Academic Year 2013/2014).

Djiwandono, S.(2008). Tes Bahasa: Pegangan bagi Para Pengajar Bahasa. Malang: PT Macanan Jaya Cemrlang.

Fachrurrazy. (2002). Teaching English as a Foreign Language. Malang: State University of Malang.

Kustanti, Dewi \& Prihmayadi (2017). Problematika Budaya Berbicara Bahasa Inggris, Jurnal al-Tsaqafa, 14(1), 169-182.

Irianto, N.A. (2018). An Analysis of Pronunciation Errors of English Consonants:/ $\theta /$ and /ठ/ by the Students of the English Education Study Program of the University of Bengkulu. Journal of English Education and Teaching, 2(3), 18-28.

Ramelan. (1999). English Phonetics. Semarang: CV.IKIP Semarang Press.

Saebani. (2016). A Study of the Fourth Semester Students of English Education Department of IAIN Salatiga. IAIN Salatiga.

Sumbayak. (2009). The Diphthong: The Obstacles For Indonesian Speaker Of English, Journal Lingua Cultura, 3(1), 107-115. 
Sefra, Syafrizal, Arasuli

An Analysis of English Diphthong

Pronunciation by the Students of the English Education Study Program

Syafriadin. (2019). Digital Storytelling Implementation for Enhancing Students' Speaking Ability in various Text Genres, International Journal of Recent Technology and Engineering, 8(4), 3147-3151. 